\title{
The impact of different agroecological conditions on the nutritional composition of quinoa seeds
}

\author{
María Reguera ${ }^{\text {Corresp., }}$ 1,2 , Carlos Manuel Conesa ${ }^{1}$, Alejandro Gil-Gómez ${ }^{1}$, Claudia Mónika Haros ${ }^{3}$, Miguel \\ Ángel Pérez-Casas ${ }^{1}$, Vilbett Briones-Labarca ${ }^{4,5,6}$, Luis Bolaños ${ }^{1}$, Ildefonso Bonilla ${ }^{1}$, Rodrigo Álvarez $^{5}$, \\ Katherine Pinto ${ }^{6}$, Ángel Mujica ${ }^{7}$, Luisa Bascuñán-Godoy ${ }^{4,6,8}$ \\ 1 Departamento de Biología, Universidad Autónoma de Madrid, Madrid, Spain \\ ${ }^{2}$ Centro de Biotecnología y Genómica de Plantas, Universidad Politécnica de Madrid (UPM) - Instituto Nacional de Investigación y Tecnología Agraria y \\ Alimentaria (INIA), Universidad Politécnica de Madrid, Madrid, Spain \\ 3 Instituto de Agroquímica y Tecnología de los Alimentos, Paterna, Valencia, Spain \\ 4 Centro de Estudios Avanzados en Zonas Áridas (CEAZA), La Serena, Chile \\ 5 Food Engineering Department, Universidad de La Serena, La Serena, Chile \\ 6 Instituto de Investigación Multidisciplinar en Ciencia y Tecnología, Universidad de La Serena, Chile \\ 7 Universidad Nacional del Altiplano, Puno, Perú \\ 8 Laboratorio de Fisiología Vegetal, Departamento de Botánica, Facultad de Ciencias Naturales y Oceanográficas, Universidad de Concepción, Concepción, \\ Chile
}

Corresponding Author: María Reguera

Email address: maria.reguera@uam.es

Quinoa cultivation has been expanded around the world in the last decade and is considered an exceptional crop with the potential of contributing to food security worldwide. The exceptional nutritional value of quinoa seeds relies on their high protein content, their amino acid profile that includes a good balance of essential amino acids, the mineral composition and the presence of antioxidants and other important nutrients such as fiber or vitamins. Although several studies have pointed to the influence of different environmental stresses in certain nutritional components little attention has been paid to the effect of the agroecological context on the nutritional properties of the seeds what may strongly impact on the consumer food's quality. Thus, aiming to evaluate the effect of the agroecological conditions on the nutritional profile of quinoa seeds we analyzed three quinoa cultivars (Salcedo-INIA, Titicaca and Regalona) at different locations (Spain, Peru and Chile). The results revealed that several nutritional parameters such as the amino acid profile, the protein content, the mineral composition and the phytate amount in the seeds depend on the location and cultivar while other parameters such as saponin or fiber were more sable across locations. Our results support the notion that nutritional characteristics of seeds may be determined by seed's origin and further analysis are needed to define the exact mechanisms that control the changes in the seeds nutritional properties. 


\section{The impact of different agroecological conditions on the nutritional}

\section{2 composition of quinoa seeds}

3 Reguera M. ${ }^{1,2^{*}}$, Conesa C.M. ${ }^{1}$, Gil-Gómez A. ${ }^{1}$, Haros M. ${ }^{3}$, Pérez-Casas M.A. ${ }^{1}$, Briones-Labarca,

4 V. 4,6,8 , Bolaños L. ${ }^{1}$, Bonilla I. ${ }^{~}$, Alvarez R. ${ }^{4}$, Pinto K. ${ }^{6}$, Mujica A. ${ }^{7}$ \& Bascuñán-Godoy L. ${ }^{5,6,8}$

$5 \quad{ }^{1}$ Departamento de Biología, Universidad Autónoma de Madrid, Madrid, Spain

6 2Present address: Centro de Biotecnología y Genómica de Plantas, Universidad Politécnica de Madrid (UPM) -

7 Instituto Nacional de Investigación y Tecnología Agraria y Alimentaria (INIA), Universidad Politécnica de Madrid,

8 Madrid, Spain

$9 \quad{ }^{3}$ Instituto de Agroquímica y Tecnología de Alimentos (IATA-CSIC), Paterna, Valencia, Spain.

$10{ }^{4}$ Centro de Estudios Avanzados en Zonas Áridas (CEAZA), La Serena, Chile.

$11 \quad{ }^{5}$ Food Engineering Department, Universidad de La Serena, La Serena, Chile

12 Instituto de Investigación Multidisciplinar en Ciencia y Tecnología, Universidad de La Serena, Chile.

$13 \quad{ }^{7}$ Universidad Nacional del Altiplano Escuela de Postgrado, Puno, Perú.

$14{ }^{8}$ Laboratorio de Fisiología Vegetal, Departamento de Botánica, Facultad de Ciencias Naturales y Oceanográficas, 15 Universidad de Concepción, Concepción, Chile.

16 *Author for correspondence: Maria Reguera

17 Email: maria.reguera@uam.es 
23 Quinoa cultivation has been expanded around the world in the last decade and is considered an

24 exceptional crop with the potential of contributing to food security worldwide. The exceptional

25 nutritional value of quinoa seeds relies on their high protein content, their amino acid profile that

26 includes a good balance of essential amino acids, the mineral composition and the presence of

27 antioxidants and other important nutrients such as fiber or vitamins. Although several studies have

28 pointed to the influence of different environmental stresses in certain nutritional components little

29 attention has been paid to the effect of the agroecological context on the nutritional properties of

30 the seeds what may strongly impact on the consumer food's quality. Thus, aiming to evaluate the

31 effect of the agroecological conditions on the nutritional profile of quinoa seeds we analyzed three

32 quinoa cultivars (Salcedo-INIA, Titicaca and Regalona) at different locations (Spain, Peru and

33 Chile). The results revealed that several nutritional parameters such as the amino acid profile, the

34 protein content, the mineral composition and the phytate amount in the seeds depend on the

35 location and cultivar while other parameters such as saponin or fiber were more sable across

36 locations. Our results support the notion that nutritional characteristics of seeds may be determined

37 by seed's origin and further analysis are needed to define the exact mechanisms that control the

38 changes in the seeds nutritional properties.

\section{Introduction}


44 Chenopodium quinoa Willd commonly known as quinoa, belongs to the family Amaranthaceae

45 [1]. Quinoa is mainly growing in the arid and semi-arid areas of the Andean region of South

46

47

America although its cultivation has been expanded worldwide [2,3]. It is well adapted to extreme conditions including water deficits, low temperatures, salinity and poor soils and it can grow at sea level up to elevations of 4000 meters above the sea [4-7]. In the last years, quinoa has gained worldwide attention due to the remarkable nutritional properties of its seeds, that include high protein content and essential amino acids (including lysine), fats, flavonoids, vitamins and minerals and as a gluten-free product [8-11]. The seeds, leaves, tender stems and inflorescences can be consumed in the human diet and as animal feed. Also, quinoa leaves are rich in phenolic compounds (including ferulic, sinapinic, gallic acid, kaempferol, isorhamnetin, or rutin) that possess antioxidant and anticancer properties [12]. Due to the high nutritional value of quinoa, its genetic diversity and its great adaptability to stressful environments, it has been considered an exceptional crop with the potential of contributing to food security worldwide [3].

The quality of the seeds and other plant organs is a complex trait that results from the interaction of genetic and environmental factors [13]. Breeding programs in quinoa have mainly focused on the generation of better environmentally adapted plants with improved resistance to mildew aiming to develop high-yielding varieties allowing the worldwide crop expansion $[14,15]$. Less attention has been paid to the seed nutritional properties when developing new quinoa varieties. However, the improvement of quinoa seed quality is challenging and key for food security and has been almost exclusively focused on generating hybrid varieties with lower saponin contents (sweet varieties) [15].

The impact of agroecological conditions or agronomic practices on the quinoa nutritional quality has been little explored. Nonetheless, several studies point to the importance of environmental or 
67 agronomical factors affecting the nutritional properties (such as the amino acid profile or the

68 protein content) of quinoa seeds including drought, salinity or the cultivation area [16-20]. Still,

69 the information regarding the mechanisms that control seed nutritional properties is scarce.

70 Overall, knowing that the nutritional properties of quinoa seeds are determined by the 71 concentration of nutrients (i.e. amino acid content), their balance and quality (i.e. protein quality

72 or the amino acid profile) and their bioavailability (determined by components such as phytate content), our working hypothesis states that the environmental and climatic factors as well as the agronomical practices used can significantly affect the nutritional quality of quinoa seeds. In order to analyze the impact of these factors, three quinoa cultivars were selected (Salcedo-INIA, Titicaca and Regalona) and their agronomical performance and nutritional characteristics were evaluated at different locations (Spain, Peru and Chile). The results revealed that several nutritional parameters such as the protein content, the amino acid profile or the mineral composition of the seeds change with the location and cultivar while other parameters such as saponin, remained unchanged among the varieties and locations studied.

\section{Material and Methods}

\section{Plant material, experimental design and locations}

83 Quinoa (Chenopodium quinoa Willd.) seeds of cultivars Regalona (registered variety of BAER, Chile), Salcedo-INIA (experimental station of Illpa - Puno, Peru, [21]) and Titicaca (generously provided by Dr. Jacobsen of Copenhagen University) were selected to evaluate their agronomic potential and seed nutritional traits at three locations with different agroecological conditions: El

87 Pobo (Teruel, Spain), Arequipa (Peru) and Río Hurtado (Chile). The field experiment at El Pobo 
89

90

91

92

93

94

95

96

97

and October 2016 within a range of temperatures between 24.1 and $4.7^{\circ} \mathrm{C}$ on average (registering a maximum of $32.3{ }^{\circ} \mathrm{C}$ and a minimum of $-2.8{ }^{\circ} \mathrm{C}$ ) and $194 \mathrm{~mm}$ total precipitation during the mentioned period. The field trial at Río Hurtado $\left(30.3^{\circ} \mathrm{S}, 70.6^{\circ} \mathrm{W}, 1462 \mathrm{~m}\right.$ a.s.1.) (Chile), was carried out between November 2015 and April 2016 within a range of temperatures between 11 and $25^{\circ} \mathrm{C}$ on average (registering a maximum of $34^{\circ} \mathrm{C}$ and a minimum of $3.7^{\circ} \mathrm{C}$ ). The total precipitation during that period was $150 \mathrm{~mm}$ and the irrigation was applied using drip lines that released $4 \mathrm{~L} \mathrm{~m}^{-1} \mathrm{~h}^{-1}$ according to Martinez et al 2009 [22]. In Arequipa (16 ${ }^{\circ} \mathrm{S}, 71^{\circ} \mathrm{W}, 2355 \mathrm{~m}$ a.s.1.) the experiment was carried out under irrigation between March and July 2016 with an average temperature of $14{ }^{\circ} \mathrm{C}$ (registering a maximum of $28.8^{\circ} \mathrm{C}$ and a minimum of $4.2^{\circ} \mathrm{C}$ ) and $15.3 \mathrm{~mm}$ total precipitation.

The soil type in Spain (a clay-silty-loam soil) presented a $\mathrm{pH}$ of $7.9,4.8 \%$ organic matter, 3 dS.m ${ }^{-1}$ of electrical conductivity (EC) of the saturated paste and phosporous (P) and potassium (K) equivalent to 37 and 438 mg. $\mathrm{kg}^{-1}$, respectively. The soil type in Chile (a loamy alluvial Entisol) presented a $\mathrm{pH}$ of $7.8,7.7 \%$ of organic matter, $2.6 \mathrm{dS} \mathrm{m}^{-1}$ of EC and content of $\mathrm{P}$ and exchangeable $\mathrm{K}$ equivalent to 49.96 and $237 \mathrm{mg} \mathrm{kg}^{-1}$, respectively. The soil type in Arequipa (Peru) (a loam soil) presented $4.89 \%$ of organic matter, $2.25 \mathrm{dS} \mathrm{m}^{-1}$ of EC, a $\mathrm{pH}$ of 6.95 and a content of 39.31 mg.kg-1 of $\mathrm{P}$ and $624.96 \mathrm{mg} . \mathrm{kg}^{-1}$ of $\mathrm{K}$.

The experimental design consisted in randomized blocks $\left(8 \mathrm{~m}^{2}\right.$ per block, $\left.4 \mathrm{~m} \times 2 \mathrm{~m}, \mathrm{~L} \times \mathrm{W}\right)$ with 4 replications in each location using the three varieties (Regalona, Salcedo-INIA and Titicaca). Each block was composed of 4 rows of $4 \mathrm{~m}$ in length (row spacing=50 cm). Seeds were directly germinated in the soil with a sowing density of $10 \mathrm{~kg} / \mathrm{ha}$ between 1 and $2.5 \mathrm{~cm}$ depth.

\section{Quantitative multi-elemental analysis}


111 Quantitative multi-elemental analysis by inductively coupled plasma (ICP) spectrometry was used

112 to determine total content of calcium $(\mathrm{Ca})$, magnesium $(\mathrm{Mg})$, iron $(\mathrm{Fe})$, sodium $(\mathrm{Na})$, zinc $(\mathrm{Zn}), \mathrm{P}$

113 and $\mathrm{K}$ contents in C. quinoa seeds. Seed samples were firstly grinded to a fine powder. The samples

114 were then submitted to the Interdepartmental Investigation Service Laboratory at the Universidad

115 Autónoma de Madrid (SIdI-UAM, Madrid, Spain). Samples were digested in a microwave oven

116 and subsequently analyzed using the equipment ICP-MS NexION 300XX (Perkin Elmer Inc.,

117 Massachusetts, USA).

118 Total Phytate content

119 Total phytate content was determined using Myo-Inositol Hexakisphosphate Determination

120 method. This method involved acid extraction of myo-inositol phosphates from $0.5 \mathrm{~g}$ of flour

121 (ground seeds) in $20 \mathrm{~mL}$ of $\mathrm{HCl} 0.66 \mathrm{M}$ with vigorously stirring at room temperature overnight

122 followed by treatment with a phytase and alkaline phosphatase (Megazyme K-PHYT 07/11

123 Wicklow, Ireland). The total phosphate released was proportional to myo-inositol

124 hexakisphosphate in non-processed seeds. It was measured using a colorimetric method with 125 ammonium molybdate reactive to form 12-molybdophosphoric acid, which was subsequently

126 reduced under acidic conditions to molybdenum blue. The amount of molybdenum blue formed in

127 the reaction was proportional to the amount of free phosphate present in the sample and was

128 measured at $655 \mathrm{~nm}$ using a spectrophotometer SPECTROstar nano (BMG LabTech GmbH,

129 Ortenberg, Germany). Phosphorus was quantified by a calibration curve using standards of known

130 phosphorus concentration. The samples were done by triplicate and the results were expressed in

131 grams of phytic acid per $100 \mathrm{~g}$ of seeds in dry matter.

\section{Protein content}


133 The Kjeldahl method with a conversion factor of 6.25 by AOAC method no 960.52 (AOAC, 2016)

134 was employed to quantify the total crude protein content of the quinoa seed samples. All

135 determinations were done in triplicate.

136 Amino acid quantification

137 Liquid chromatography mass spectrometry (LC/MS) was used to determine free amino acid 138 content of $C$. quinoa seeds. Seed samples were grinded to a fine powder. Free amino acid was 139 extracted as described previously by Hacham et al. (2002)[23]. One hundred fifty mg of seed 140 powder was homogenized in $400 \mu \mathrm{L}$ water:chloroform:methanol (3:5:12 v/v) and centrifuged at $14114000 \mathrm{rpm}$ for $2 \mathrm{~min}$. This step was repeated twice and both supernatants were combined and 142 mixed with $200 \mu \mathrm{L}$ chloroform and $300 \mu \mathrm{L}$ of water. The resulting mixture was centrifuged at $14314000 \mathrm{rpm}$ for $2 \mathrm{~min}$. The supernatant (corresponding to the water:methanol phase) was subjected 144 to speed-vac to dry and resuspended in $100 \mu \mathrm{L}$ miliQ $\mathrm{H}_{2} \mathrm{O}$.

145 Free amino acid extracts were submitted to the Chromatography Laboratory at the SIdI-UAM 146 (Spain) for analysis. Amino acid determination was carried out using HPLC-MS with an Agilent 147 system detector composed by an 1100 series HPLC coupled to a single 6120 Quadrupole. For the 148 chromatographic separation, $5 \mu \mathrm{L}$ were injected in an ACE 5 AQ $(250 x 4.6 \mathrm{~mm}, 5 \mu \mathrm{m})$ thermostated 149 column at $30^{\circ} \mathrm{C}$ with $0.4 \mathrm{~mL} / \mathrm{min}$ flow rate and binary gradient elution. The elution was performed 150 in $\mathrm{H}_{2} \mathrm{O}$ with $0.1 \%$ formic acid (v/v) as eluent " $\mathrm{A}$ " and acetonitrile (ACN) with $0.1 \%$ formic acid $151(\mathrm{v} / \mathrm{v})$ as eluent "B". The gradient program was as follows for eluent B: $0 \mathrm{~min}, 0 \% ; 30 \mathrm{~min}, 100 \%$; $15235 \mathrm{~min} ; 100 \% ; 36 \mathrm{~min}, 0 \% ; 55 \mathrm{~min}, 0 \%$. The ionization parameters were as follows: positive 153 atmospheric pressure chemical ionization $(\mathrm{APcI}+)$, fragmentor voltage $40 \mathrm{~V}$, capillary voltage 2.0 $154 \mathrm{kV}$, charging voltage $2.0 \mathrm{kV}$, nebulizer pressure $20 \mathrm{psig}$, drying gas flow $5 \mathrm{~L} / \mathrm{min}$ at $350{ }^{\circ} \mathrm{C}$, 
155 vaporizer temperature $250^{\circ} \mathrm{C}$, and corona current $4 \mu \mathrm{A}$. Data was recorded scanning from 50 to 156250 Da.

157 Ferric reducing antioxidant power (FRAP) assay

158 The FRAP assay was used to determine the antioxidant capacity of seed samples. The procedure

159 described by Benzie and Strain (1996)[24] was used with some modifications. Briefly, $30 \mu \mathrm{L}$

160 sample aliquots were mixed with $90 \mu \mathrm{L}$ of distilled water and $900 \mu \mathrm{L}$ of freshly prepared FRAP

161 reagent at $37^{\circ} \mathrm{C}(2.5 \mathrm{~mL}$ of a $10 \mathrm{mmol} / \mathrm{L} \mathrm{2,4,6-tripyridyl-s-triazine} \mathrm{(TPTZ)} \mathrm{solution} \mathrm{in} 40 \mathrm{mmol} / \mathrm{L}$

$162 \mathrm{HCl}$ with $2.5 \mathrm{~mL}$ of $20 \mathrm{mmol} / \mathrm{L} \mathrm{FeCl}_{3}$ and $25 \mathrm{~mL}$ of $0.3 \mathrm{~mol} / \mathrm{L}$ acetate buffer at a $\mathrm{pH}$ of 3.6). The

163 absorbance of the reaction mixture was measured spectrophotometrically (atomic absorption

164 spectroscopy (PinAAcle 900F FL HSN, WinLab32 software; Perkin Elmer Inc., Massachusetts,

$165 \mathrm{USA}$ ) at $593 \mathrm{~nm}$ following incubation at $37^{\circ} \mathrm{C}$ for 2 hours. FRAP concentration was calculated

166 from a calibration curve obtained by linear regression and the results are expressed in Trolox

167 equivalents (mmol TE $\left.100 \mathrm{~g}^{-1}\right)$. The reference used was the synthetic antioxidant Trolox at a 168 concentration of 100 to $1500 \mathrm{mmol}$ in $80 \%$ methanol solution, which was tested under the same 169 conditions.

170 Fiber and saponin determination

171 For fiber determination samples were submitted to the SERBILAC laboratory (Universidad

172 Nacional de San Agustín de Arequipa, Peru). Fiber content was determined following the protocol 173 described in AOAC Methods 2016 [25]. Samples were submitted to the Laboratory of quality 174 control (Universidad Nacional del Altiplano Puno, Peru). Total saponin content was determined 175 spectrophotometrically at $528 \mathrm{~nm}$ using an SQ-2802 single beam scanning spectrophotometer 176 (UNICO) [26]. The concentration of saponin was read off from a standard curve of different 
177 concentrations of saponin (Calbiochem, CAS 8047-15-2, Germany) (from 0.5 to $7.5 \mathrm{mg} / \mathrm{L}$ )

178 dissolved in an aqueous solution.

179 Statistical analysis

180 Results are presented as Mean value \pm Standard Deviation or Error. Pairwise comparisons were

181 done by using Student t-test at a probability level of 5\% $(P<0,05)$. Multiple comparisons were

182 done by one-way analysis of variance (ANOVA) followed by Duncan or Tukey HSD post-hocs to 183 analyze the quantitative data at a probability level of $5 \%(P<0,05)$. The $\mathrm{JMP}^{\circledR}($ ver.11.0) statistical 184 package (SAS Institute) and the Free Software R were used for the statistical analyses.

185

186

187

188

189

190

191

192

193

194

195

196

197

198

\section{Results}

Variations in agronomical traits of Chenopodium quinoa cultivars under different agroecological conditions

Among the three quinoa varieties studied, differences were found in terms of seed yield when consider total yield and seed weight per plant (Table 1). Although a larger total yield (Kg/Ha) was achieved by Salcedo-INIA grown in Peru followed by Titicaca grown in Chile, this was due to a larger plant density in these two varieties and not because of a better variety performance as revealed by the seed weight per plant (that was the smallest in Salcedo-INIA from Peru). Also, the harvest index parameter values did not differ among the varieties tested. On the contrary, Titicaca in Spain yield less seeds than Regalona (t-Student, $P<0$,05) and Regalona showed the largest seed weight per plant among cultivars and locations. Besides, Titicaca and Regalona in Peru were unable to yield seeds and Salcedo-INIA in Spain showed important seed losses due to seed dehiscence detected at harvesting related to defects in the timing of maturity, the uniformity of maturity and the lack drydown of plant at seed maturity. 
199 Most of the morphological traits varied with the location and among cultivars (Table 1). Salcedo-

200 INIA cultivar showed the smallest plants in Chile but the biggest plants in Spain. Salcedo-INIA

201 presented the largest stem diameter and panicle length in Peru and Spain while the stem diameter

202 of Regalona was the largest in Chile. Salcedo-INIA showed the biggest panicle length among

203 varieties in the different locations. Plant weight did not differ among locations but varieties as

204 shown in Table 1.

205 Regarding the analysis of phenological traits, days to flowering and days to maturity were 206 evaluated. Titicaca showed the shortest time to flowering and to maturity at both locations (Chile 207 and Spain), followed by Regalona. Salcedo-INIA presented the largest time to flowering and 208 maturity (approximately 95 days and 184, respectively) in Spain and Chile while reduced the days 209 to flowering and maturity in Peru.

\section{Mineral composition and phytate content in $C$. quinoa seeds}

211 Quantitative multi-elemental analysis was performed aiming to assess differences in the seed mineral composition among cultivars and locations due to distinct agroecological conditions. When analyzing the effect of the location in each genotype (Fig. 1 A-C), it was observed that Regalona seeds stored larger amounts of mineral nutrients in Chile with exception of P. SalcedoINIA showed larger quantities of $\mathrm{Mg}, \mathrm{Fe}, \mathrm{Ca}$ and $\mathrm{Zn}$ in Peru, while in Chile presented the largest amount of $\mathrm{P}$ and the lowest of Na. Titicaca in Spain had larger amounts of $\mathrm{Ca}, \mathrm{K}, \mathrm{P}$ and $\mathrm{Na}$ but less amount of $\mathrm{Fe}$ and $\mathrm{Zn}$ comparing the same variety grown in Chile.

Differences among varieties were also found in each location (Fig. $1 \mathrm{C}$ and D). In Chile, Regalona largest amounts of Fe and $\mathrm{K}$. Titicaca in Chile showed the lowest contents in $\mathrm{Ca}, \mathrm{P}, \mathrm{Mg}$ and $\mathrm{Na}$ 
221 compared to the other two cultivars. In Spain, Titicaca showed the highest level of K. Salcedo-

222 INIA grown in Spain showed the highest amounts of $\mathrm{P}$ and $\mathrm{Mg}$ but smallest of $\mathrm{Fe}, \mathrm{Ca}$ and $\mathrm{Na}$. All

223 the cultivars grown in Spain or Chile showed similar Zn contents.

224 Overall, a larger accumulation of $\mathrm{Mg}$ and $\mathrm{Fe}$ tend to appear in Chile. Zn contents changed with the

225 location but remains unchanged within cultivars. Generally, the type of the cultivar and location

226 affects the content of certain minerals, indicating that both factors (variety and location) are

227 determinants of the mineral composition of quinoa seeds.

228 Phytic acid is considered an important seed component conditioning the nutritional properties of 229 seeds [27]. The analysis of phytate content in quinoa seeds (Fig. 2) revealed that Regalona seeds 230 from Spain showed the largest phytate content, followed by the Salcedo-INIA and Titicaca seeds

231 from this country. Titicaca seeds from Chile presented the smallest phytate content. The fact that

232 no differences were found among cultivars in the same location but a given genotype vary among

233 locations suggests that phytic acid content in quinoa seeds might be determined by environmental

234 factors and not by the type of cultivar.

235

236

237

238

239

240

241

Total Protein content and free amino acid profile of quinoa seeds obtained from Chile, Peru and Spain

The range of total protein content was found between 14 and 17\% among the cultivars and the locations analyzed (Fig.3). No differences were found when comparing among varieties in a particular location. Consistently, seeds from Chile showed a higher total protein content comparing to Spain or Peru. These results might suggest that agroecological conditions can influence on the protein content of the seeds. 
242 Regarding amino acid composition, the most abundant amino acids found in the quinoa seeds

243 analyzed in the present study were arginine and glutamic acid (Fig 4.). Asparagine, glutamic acid,

244 glutamine, histidine, glycine, hydroxyproline, serine and threonine remained unchanged in all

245 cultivars and locations. The rest of the amino acids quantified showed differences among cultivars

246 and/or locations. For instance, Regalona seeds grown in Spain showed higher contents of arginine,

247 aspartic acid, lysine and methionine compared to the Chilean Regalona seeds. Spanish Salcedo-

248 INIA seeds showed larger contents of aspartic acid, isoleucine, leucine and valine compared to the

249 Peruvian and Chilean Salcedo-INIA seeds. Arginine and phenylalanine showed higher contents in

250 Salcedo-INIA seeds obtained from Spain when compared with the seeds from Chile but no

251 differences were detected in the contents of these two amino acids between Spain and Peru.

252 Noteworthy, an elevated amount of tryptophan was found in Salcedo-INIA from Peru, amount

253 that was superior to any of the cultivars analyzed. In Spain, the amount of lysine in Regalona and

254 valine in Salcedo-INIA were higher when compared to other cultivars or locations. In contrast, the 255 content of amino acids in Titicaca did not change significantly among cultivars nor locations.

When analyzing the amino acid content by location it was observed that the varieties grown in

Chile did not present differences in their amino acid content. However, inter cultivar differences were observed in the amino acid contents in the Spanish quinoa seeds for alanine, asparagine, isoleucine, lysine and valine.

Antioxidant properties of quinoa seeds in different cultivars and locations

Antioxidant capacity varied among cultivars and locations ranging from 0.75 to $0.15 \mathrm{mmol} \mathrm{TE}$ 
265 measured as FRAP, while Salcedo-INIA from Peru presented the lowest values. The big

266 differences observed between the antioxidant properties of Regalona at the two locations studied

267 did not appear in Titicaca nor Salcedo-INIA (differences among locations in these two cultivars

268 were much smaller) what would indicate that changes among cultivars appear when evaluating the

269 effect of the agroecological conditions on the antioxidant properties.

\section{Fiber and saponin contents}

271 Although no differences were found in the saponin content (Figure 6a) among the cultivars or

272 locations, Titicaca seeds from Chile showed larger fiber contents compared to Regalona seeds

273 obtained from Spain (Figure 6b). These results might indicate that fiber might be more susceptible

274 to variations associated with changes in agroecological conditions despite no big differences were

275 found among cultivars and locations.

\section{Discussion}

277 Quinoa is able to grow under a wide variety of environmental conditions and to tolerate a broad

278 range of stresses which in addition to the excellent nutritional properties of its seeds makes this

279 crop an attractive and feasible option from an agronomic perspective [28,29]. Numerous studies

280 have been published in the last years describing the effect of different abiotic stresses on quinoa,

281 however, the analysis of how quinoa responds to a certain environment altering the nutritional

282 properties of the seeds has been little explored. Here, we have analyzed how different agroecological conditions can induce distinct agronomical and nutritional responses depending on

284 the variety of quinoa considered. We observed that despite some traits were largely influenced by 285 the genotype, such as the phenological characters [30], others were more sensitive to the interaction 286 between the genotype and the environment resulting in specific responses. 
287 The analysis of the mineral composition is crucial when considering the nutritional quality of the

288 seeds [31]. The mineral concentration of the quinoa seeds evaluated in the present study was found

289 within a range similar to what was previously reported in quinoa (Supplementary table 1) [32-34].

290 Interestingly, the accumulation of some minerals was heavily influenced by the location

291 considered. For instance, the amount of Ca varied up to 2.6 times among locations in Salcedo-

292 INIA cultivar. These variations could significantly impact on the consumer. For instance, the

293 dietary reference intake (DRI) for Fe in women between 19 and 30 years old stablished by the US

294 government [35] corresponds to $18 \mathrm{mg}$ /day which could be covered with the uptake of $200 \mathrm{~g}$ of the

295 Regalona seeds from Chile instead of the 400g required when consuming Regalona seeds from

296 Spain. The differences observed in the mineral composition may be caused by a strong effect of

297 the environment, and we hypothesized that one of the main contributing factors could be the soil

298 composition. Previous studies growing quinoa under different agroecological conditions are in

299 agreement with our results and hypothesis [32,34], and can be extended as well to the effects

300 observed on the grains and seeds of other crop species such as wheat, pea and corn [36-38].

301 One of the most attractive features of quinoa is the high protein content and the good balance of 302 amino acids in the seeds [29]. Both were shown to rely on nitrogen metabolism which is known to 303 be regulated by agroecological factors such as abiotic stresses (i.e. water stress) or soil factors (i.e. 304 nitrogen fertilization) [18,39-41]. Although the total protein content was found within a range 305 already described for quinoa seeds (between 15 and 20\%) [28,33], our results suggest that the 306 environmental conditions could determine the protein content found in quinoa. Similarly, 307 Gonzalez and coworkers found changes in the protein content of ten quinoa cultivars growing in 308 two different agroecological regions [17]. Other studies, however, have shown no differences in 309 the protein content when comparing quinoa seeds growing in two environments [34], suggesting 
310 that the interaction of environmental conditions and genotype plays an important role modulating

311 the protein content in the seeds.

312 The analysis of the seed free amino acid profile revealed also variations associated with the cultivar

313 and location. The presence of essential amino acids (EAA), including methionine, threonine or

314 lysine, contributes to the high nutritional properties of the quinoa seeds and can vary when plants

315 are subjected to abiotic stress $[18,42]$. Among the EAA analyzed in this study, only threonine and

316 histidine remained stable in all cases, and changes were observed in the rest of EAA. These results

317 support previous findings that claimed that the EAA content can vary significantly depending on

318 the genotype and seed's origin [17]. Thanapornpoonpong and coworkers found that nitrogen

319 availability determines not only the protein content but also the amino acid composition of quinoa

320 seeds [40]. Taken all together, these findings suggest that a complex genotype $\mathrm{x}$ environment

321 interaction alters nitrogen metabolism resulting in seed nutritional differences. Nonetheless, the

322 main and specific factors contributing to these changes remain to be elucidated.

323 Different bioactive components contribute to the antioxidant capacity of quinoa seeds including 324 polyphenols, flavonoids and vitamins (A, B and E) [29], which may prevent cancer, cardiovascular 325 and other, chronic diseases [43]. The amount of these phytochemicals in quinoa seems to be 326 genotype-specific and could vary significantly under stressful conditions [18,20]. Our results 327 showed differences among cultivars and locations in agreement with the results obtained by 328 Miranda and co-workers [34], what highlights the importance of the environmental factors 329 conditioning the accumulation of antioxidants in the seeds. In the present study, was especially 330 noticeable the antioxidant capacity of the Chilean cultivars that tended to have the greatest values 331 when comparing among locations. 
332 The total fiber content in quinoa seeds was found within the characteristic range [29]. Little

333 variation was observed among cultivars and locations suggesting that this parameter might be less

334 sensitive to agroecological variations. Nonetheless, Miranda and coworkers reported that the

335 changes in fiber contents only occurred in the soluble dietary fraction and no alteration was

336 detected in the total fiber, indicating that both fractions might be affected differently [34].

337 Saponin and phytic acid have been traditionally considered antinutrients that diminish the 338 nutritional value of seeds due to their ability to alter the absorption of minerals $[28,44]$. However, 339 several studies have pointed to the beneficial effects associated to these two compounds [45]. In 340 the case of saponin different breeding programs have aimed to develop quinoa varieties with a 341 lower saponin content trying to increase the palatability of the seeds increasing consumers 342 acceptance $[15,46]$. Besides being determined by the variety, recent evidences have suggested that 343 external factors might impact on saponin contents of quinoa seeds. For instance, it was reported 344 that the saponin content of Q52 variety diminished under water or salinity stress [11]. Also, it was 345 shown that the saponin content was altered in Regalona seeds when growing at different locations 346 [34]. Nonetheless, our results did not find differences in the saponin content in any of the cultivars 347 or locations analyzed supporting the hypothesis that claims that this trait is largely determined by 348 the variety more than being environmentally regulated.

349 A different response was observed regarding phytic acid whose content varied with the location 350 suggesting that this might modulate its accumulation. To our knowledge, no previous studies have 351 been carried out evaluating the effect of environmental factors in quinoa seed phytate composition.

352 In oat, barley and dry beans was described a strong effect of agroecological conditions in their 353 phytate content [47-49]. However, the exact factors that cause these changes remain unclear. 354 Considering that phytic acid contributes extensively to the nutritional profile of quinoa seeds it 
355 should be stressed that further studies are needed in the field to deeply analyze the contributing

356 environmental factors involved in phytate seed accumulation.

\section{Conclusions}

358 Our results highlight that different agroecological conditions could significantly alter the 359 agronomical and nutritional properties of quinoa what impacts on the seed quality. Although not 360 all the nutritional traits evaluated varied in the same extent, one can affirm that both, the variety 361 and location, determined the mineral composition, the amino acid profile, the protein content and

362 the antioxidant capacity of the quinoa seeds. Therefore, when evaluating the nutritional quality of 363 quinoa seeds and in order to provide precise nutritional information to the consumer we should 364 considered the cultivar and the agroecological context. This work also provides valuable 365 information that could be used in breeding programs to maximize the potential of this crop by 366 defining stable varieties and/or environments from a nutritional point of view.

\section{Acknowledgments}

368 We thank Dr. Sven Jacobsen from the University of Copenhagen for providing us with the Titicaca

369 Chenopodium quinoa seeds used in this study. We also thank Karla Miranda Ramos for the 370 technical assistance with the phytic acid determination, Rosa Sedano Pérez for her technical 371 assistance with the amino acid determination, Inmaculada Rivas Ramírez for her technical 372 assistance with the minerals quantification and Susana Vilariño for the stimulating discussions that 373 have helped improving this manuscript. 
376 [1] D. Cusack, Quinua: grain of the Incas, Ecologist. 14 (1984) 21-31.

377 [2] R. Choukr-Allah, N.K. Rao, A. Hirich, M. Shahid, A. Alshankiti, K. Toderich, S. Gill, 378 K.U.R. Butt, Quinoa for Marginal Environments: Toward Future Food and Nutritional Security in 379 MENA and Central Asia Regions, Front. Plant Sci. 7 (2016) 346. doi:10.3389/fpls.2016.00346.

380 [3] D. Bazile, C. Pulvento, A. Verniau, M.S. Al-Nusairi, D. Ba, J. Breidy, L. Hassan, M.I. 381 Mohammed, O. Mambetov, M. Otambekova, N.A. Sepahvand, A. Shams, D. Souici, K. Miri, S. 382 Padulosi, Worldwide Evaluations of Quinoa: Preliminary Results from Post International Year of 383 Quinoa FAO Projects in Nine Countries, Front. Plant Sci. 7 (2016) 850. 384 doi:10.3389/fpls.2016.00850.

385 [4] V.I. Adolf, S.-E. Jacobsen, S. Shabala, Salt tolerance mechanisms in quinoa (Chenopodium 386 quinoa Willd.), Environ. Exp. Bot. 92 (2013) 43-54. doi:10.1016/j.envexpbot.2012.07.004.

387 [5] S.-E. Jacobsen, A. Mujica, C.R. Jensen, The Resistance of Quinoa ( Chenopodium quinoa 388 Willd.) to Adverse Abiotic Factors, Food Rev. Int. 19 (2003) 99-109. doi:10.1081/FRI389120018872.

390 [6] S.-E. Jacobsen, C. Monteros, L.J. Corcuera, L.A. Bravo, J.L. Christiansen, A. Mujica, Frost 391 resistance mechanisms in quinoa (Chenopodium quinoa Willd.), 2007. 392 doi:10.1016/j.eja.2007.01.006.

393 [7] K.B. Ruiz, S. Biondi, R. Oses, I.S. Acuña-Rodriguez, F. Antognoni, E.A. Martinez394 Mosqueira, A. Coulibaly, A. Canahua-Murillo, M. Pinto, A. Zurita-Silva, D. Bazile, S.-E. 395 Jacobsen, M.A. Molina-Montenegro, Quinoa biodiversity and sustainability for food security 396 under climate change. A review, Springer Paris, 2014. doi:10.1007/s13593-013-0195-0. 
397 [8] L. Alvarez-Jubete, E.K. Arendt, E. Gallagher, Nutritive value of pseudocereals and their 398 increasing use as functional gluten-free ingredients, Trends Food Sci. Technol. 21 (2010) 106399 113. doi:10.1016/j.tifs.2009.10.014.

400 [9] M. Lutz, A. Martínez, E.A. Martínez, Daidzein and Genistein Contents in seeds of quinoa 401 (Chenopodium quinoa Willd.) from local ecotypes grown in arid Chile, Ind. Crops Prod. 49 (2013) 402 117-121. doi:10.1016/j.indcrop.2013.04.023.

403 [10] P. Paśko, M. Sajewicz, S. Gorinstein, Z. Zachwieja, Analysis of selected phenolic acids 404 and flavonoids in Amaranthus cruentus and Chenopodium quinoa seeds and sprouts by HPLC, 405 Acta Chromatogr. 20 (2008) 661-672. doi:10.1556/AChrom.20.2008.4.11.

406 [11] A.M. Gómez-Caravaca, G. Iafelice, A. Lavini, C. Pulvento, M.F. Caboni, E. Marconi, 407 Phenolic compounds and saponins in quinoa samples (Chenopodium quinoa Willd.) grown under 408 different saline and nonsaline irrigation regimens, J. Agric. Food Chem. 60 (2012) 4620-4627. 409 doi:10.1021/jf3002125.

410

[12] U. Gawlik-Dziki, M. Świeca, M. Sułkowski, D. Dziki, B. Baraniak, J. Czyż, Antioxidant 411 and anticancer activities of Chenopodium quinoa leaves extracts - In vitro study, Food Chem. 412 Toxicol. 57 (2013) 154-160. doi:10.1016/j.fct.2013.03.023.

413 [13] R. Wimalasekera, Role of Seed Quality in Improving Crop Yields, in: Crop Prod. Glob. 414 Environ. Issues, Springer International Publishing, Cham, 2015: pp. 153-168. doi:10.1007/978-3415 319-23162-4_6.

416 [14] D. Bazile, S.-E. Jacobsen, A. Verniau, The Global Expansion of Quinoa: Trends and 417 Limits., Front. Plant Sci. 7 (2016) 622. doi:10.3389/fpls.2016.00622. 
418 [15] A. Zurita-Silva, F. Fuentes, P. Zamora, S.-E. Jacobsen, A.R. Schwember, Breeding quinoa 419 (Chenopodium quinoa Willd.): potential and perspectives, Mol. Breed. 34 (2014) 13-30. 420 doi:10.1007/s11032-014-0023-5.

421 [16] F.E. Prado, J.L. Fernández-Turiel, M. Tsarouchi, G.K. Psaras, J.A. González, Variation of 422 Seed Mineral Concentrations in Seven Quinoa Cultivars Grown in Two Agroecological Sites, 423 Cereal Chem. J. 91 (2014) 453-459. doi:10.1094/CCHEM-08-13-0157-R.

424 [17] J.A. Gonzalez, Y. Konishi, M. Bruno, M. Valoy, F.E. Prado, Interrelationships among seed 425 yield, total protein and amino acid composition of ten quinoa (Chenopodium quinoa) cultivars 426 from two different agroecological regions, J. Sci. Food Agric. 92 (2012) 1222-1229. 427 doi:10.1002/jsfa.4686.

428 [18] L. Bascuñan-Godoy, M. Reguera, Y.M. Abdel-Tawab, E. Blumwald, Water deficit stress429 induced changes in carbon and nitrogen partitioning in Chenopodium quinoa Willd., Planta. (2015) 430 591-603. doi:10.1007/s00425-015-2424-z.

431 [19] G. Wu, A.J. Peterson, C.F. Morris, K.M. Murphy, Quinoa Seed Quality Response to 432 Sodium Chloride and Sodium Sulfate Salinity, Front. Plant Sci. 7 (2016). 433 doi:10.3389/fpls.2016.00790.

434 [20] I. Aloisi, L. Parrotta, K.B. Ruiz, C. Landi, L. Bini, G. Cai, S. Biondi, S. Del Duca, New 435 Insight into Quinoa Seed Quality under Salinity: Changes in Proteomic and Amino Acid Profiles, 436 Phenolic Content, and Antioxidant Activity of Protein Extracts., Front. Plant Sci. 7 (2016) 656. 437 doi:10.3389/fpls.2016.00656.

438 [21] J. Mujica, A. Izquierdo, J. Marathee, Origen y descripción de la quinua. Organización de 439 las Naciones Unidas para la Alimentación y la Agricultura., in: FAO. Quinua, Ancestral Cultiv. 
440 Andin. Aliment. Del Present. Y Futur. Santiago Chile, Chile. FAO. Univ. Nac. Del Altiplano Puno, 441 2001: pp. 9-53.

442 [22] E.A. Martinez, E. Veas, C. Jorquera, R. San Martin, P. Jara, Re-Introduction of Quinoa 443 into Arid Chile: Cultivation of Two Lowland Races under Extremely Low Irrigation, J. Agron. 444 Crop Sci. 195 (2009) 1-10. doi:10.1111/j.1439-037X.2008.00332.x.

445 [23] Y. Hacham, T. Avraham, R. Amir, The N-Terminal Region of Arabidopsis cystathionine 446 gamma-synthase plays an important regulatory role in methionine metabolism, PLANT Physiol. 447128 (2002) 454-462. doi:10.1104/pp.010819.

448 [24] J. Benzie, J. Strain, The ferric reducing ability of plasma (FRAP) as a measure of 449 “antioxidant power": the FRAP assay, Anal. Biochem. 239 (1996) 70-76.

450 [25] J. Dr. George W. Latimer, Official Methods of Analysis of AOAC International. Book by 451 AOAC International, 2016., 2016.

452 [26] M. Lozano, E. Ticona, C. Carrasco, Y. Flores, G. Almanza, Revista boliviana de quimica., 453 [Universidad Mayor de San Andres], 2012. https://lup.lub.lu.se/search/publication/3a936e80454 7429-47cf-aa68-cc0da792f098 (accessed January 3, 2018).

455 [27] J. Lott, I. Ockendena, V. Raboya, G.D. Battena, Phytic acid and phosphorus in crop seeds 456 and fruits: a global estimate, Seed Sci. Res. 10 (2000) 11-33. doi:10.1017/S0960258500000039.

457 [28] M. Jancurová, L. Minarovičová, A. Dandár, Quinoa - A review, Czech J. Food Sci. 27 458 (2009) 71-79. doi:10.4314/tjpr.v5i1.14634. 
459 [29] A.M.M. Filho, M.R. Pirozi, J.T.D.S. Borges, H.M. Pinheiro Sant'Ana, J.B.P. Chaves, 460 J.S.D.R. Coimbra, Quinoa: Nutritional, functional, and antinutritional aspects, Crit. Rev. Food Sci. 461 Nutr. 57 (2017) 1618-1630. doi:10.1080/10408398.2014.1001811.

462 [30] H.D. Bertero, A.J. De La Vega, G. Correa, S.E. Jacobsen, A. Mujica, Genotype and 463 genotype-by-environment interaction effects for grain yield and grain size of quinoa 464 (Chenopodium quinoa Willd.) as revealed by pattern analysis of international multi-environment 465 trials, F. Crop. Res. 89 (2004) 299-318. doi:10.1016/j.fcr.2004.02.006.

466 [31] M.C. Vaz Patto, R. Amarowicz, A.N.A. Aryee, J.I. Boye, H.-J. Chung, M.A. Martín467 Cabrejas, C. Domoney, Achievements and Challenges in Improving the Nutritional Quality of 468 Food Legumes, CRC. Crit. Rev. Plant Sci. $34 \quad$ (2015) 105-143. 469 doi:10.1080/07352689.2014.897907.

470 [32] F.E. Prado, J.L. Fernández-Turiel, M. Tsarouchi, G.K. Psaras, J.A. González, Variation of 471 seed mineral concentrations in seven quinoa cultivars grown in two agroecological sites, Cereal 472 Chem. 91 (2014) 453-459. doi:10.1094/CCHEM-08-13-0157-R.

473 [33] M. Miranda, A. Vega-gálvez, I. Quispe-fuentes, M.J. Rodríguez, Nutritional aspects of six 474 quinoa (Chenopodium quinoa WILLD.) ecotypes from three geographical areas of Chile, Chil. J. 475 Agric. Res. 72 (2013) 175-181. doi:10.4067/S0718-58392012000200002.

476 [34] M. Miranda, A. Vega-Gálvez, E.A. Martínez, J. López, R. Marín, M. Aranda, F. Fuentes, 477 Influence of contrasting environments on seed composition of two quinoa genotypes: nutritional 478 and functional properties, Chil. J. Agric. Res. 73 (2013) 06-07. doi:10.4067/S071847958392013000200004. 
480

[35] 2015-2020

Dietary

Guidelines

health.gov,

(n.d.).

481 https://health.gov/dietaryguidelines/2015/guidelines/ (accessed January 2, 2018).

482 [36] A. Kotlarz, A. Sujak, W. Strobel, W. Grzesiak, Chemical Composition and Nutritive Value 483 of Protein of the Pea Seeds - Effect of Harvesting Year and Variety, Veg. Crop. Res. Bull. 75 484 (2011) 57-69. doi: 10.2478/v10032-011-0018-2.

485

[37] H.F. Gomez-Becerra, A. Yazici, L. Ozturk, H. Budak, Z. Peleg, A. Morgounov, T. Fahima, 486

Y. Saranga, I. Cakmak, Genetic variation and environmental stability of grain mineral nutrient 487 concentrations in Triticum dicoccoides under five environments, Euphytica. 171 (2010) 39-52. 488 doi:10.1007/s10681-009-9987-3.

489

[38] R. Gu, F. Chen, B. Liu, X. Wang, J. Liu, P. Li, Q. Pan, J. Pace, A.A. Soomro, T. 490

Lübberstedt, G. Mi, L. Yuan, Comprehensive phenotypic analysis and quantitative trait locus 491 identification for grain mineral concentration, content, and yield in maize (Zea mays L.), Theor. 492 Appl. Genet. 128 (2015) 1777-1789. doi:10.1007/s00122-015-2546-5.

493

[39] H. Geren, Effects of different nitrogen levels on the grain yield and some yield components 494 of quinoa (Chenopodium quinoa Willd.) under menditerranean climatic conditions, Turkish J. F. 495 Crop. 20 (2015) 59-64.

496 [40] S.N. Thanapornpoonpong, S. Vearasilp, E. Pawelzik, S. Gorinstein, Influence of various 497 nitrogen applications on protein and amino acid profiles of amaranth and quinoa, J. Agric. Food 498 Chem. 56 (2008) 11464-11470. doi:10.1021/jf802673x.

499 [41] V.A. Varisi, L.S. Camargos, L.F. Aguiar, R.M. Christofoleti, L.O. Medici, R.A. Azevedo, 500 Lysine biosynthesis and nitrogen metabolism in quinoa (Chenopodium quinoa): Study of enzymes 
501 and nitrogen-containing compounds, Plant Physiol. Biochem. $46 \quad$ (2008) 11-18. 502 doi:10.1016/j.plaphy.2007.10.001.

503 [42] V. Joshi, J.-G. Joung, Z. Fei, G. Jander, Interdependence of threonine, methionine and 504 isoleucine metabolism in plants: accumulation and transcriptional regulation under abiotic stress, 505 Amino Acids. 39 (2010) 933-947. doi:10.1007/s00726-010-0505-7.

506 [43] Y. Tang, R. Tsao, Phytochemicals in quinoa and amaranth grains and their antioxidant, 507 anti-inflammatory, and potential health beneficial effects: a review, Mol. Nutr. Food Res. 61 508 (2017) 1600767. doi:10.1002/mnfr.201600767.

509 [44] J. Ruales, B.M. Nair, Saponins, phytic acid, tannins and protease inhibitors in quinoa 510 (Chenopodium quinoa, Willd) seeds, Food Chem. 48 (1993) 137-143. doi:10.1016/0308511 8146(93)90048-K.

512 [45] Y. Yao, X. Yang, Z. Shi, G. Ren, Anti-Inflammatory Activity of Saponins from Quinoa 513 (Chenopodium quinoa Willd.) Seeds in Lipopolysaccharide-Stimulated RAW 264.7 Macrophages 514 Cells, J. Food Sci. 79 (2014) H1018-H1023. doi:10.1111/1750-3841.12425.

515 [46] V. Nowak, J. Du, U.R. Charrondière, Assessment of the nutritional composition of quinoa 516 (Chenopodium quinoa Willd.), Food Chem. $193 \quad$ (2016) 47-54. 517 doi:10.1016/j.foodchem.2015.02.111.

518 [47] G.A. Miller, V.L. Youngs, E.S. Oplinger, Environmental and cultivar effects on oat phytic 519 acid concentration, Cereal Chem. 57 (1980) 189-191. 
520 [48] F. Dai, J. Wang, S. Zhang, Z. Xu, G. Zhang, Genotypic and environmental variation in 521 phytic acid content and its relation to protein content and malt quality in barley, Food Chem. 105

522 (2007) 606-611. doi:10.1016/j.foodchem.2007.04.019.

523 [49] N. Wang, A. Hou, J. Santos, L. Maximiuk, Effects of cultivar, growing location, and year 524 on physicochemical and cooking characteristics of dry beans (Phaseolus vulgaris), Cereal Chem. 52594 (2017) 128-134. doi:10.1094/CCHEM-04-16-0124-FI.

527 Figure legends

528

529

530

531

532

533

534

535

536

537

538

539

540

541

Figure 1. Mineral composition of three cultivars of $C$. quinoa seeds growing at three different

locations. Quantitative multi-elemental analysis was performed using inductively coupled plasma (ICP) spectrometry and the total content of $\mathrm{P}, \mathrm{K}, \mathrm{Ca}, \mathrm{Mg}, \mathrm{Fe}, \mathrm{Na}$ and $\mathrm{Zn}$ were determined. Three cultivars (Regalona, Salcedo-INIA and Titicaca) grown at three different locations (Peru, Chile and Spain) were used to evaluate changes in the mineral composition associated with different agroecological conditions. (A-C) Mineral composition of one variety comparing among countries (Red: Chile; Black: Peru; Blue: Spain) (A) Regalona, (B) Salcedo-INIA and (C) Titicaca. (D-E) Mineral composition of seeds from Spain or Chile comparing among varieties (Red: Regalona; Black: Salcedo-INIA; Blue: Titicaca), (D) Chile and (E) Spain. Values are presented as the Mean relative to the maximum and minimum values for each element $(n=4)$. Asterisks indicate statistical differences at a $P<0.05$ (Tukey t-test or Student t-Test when comparing pairs). When more than 2 samples are compared, colored asterisks indicate the sample that is statistically significant.

Figure 2. Phytic acid content among three varieties of $C$. quinoa seeds growing at different locations. Phytic acid content of quinoa seeds was determined using the myo-inositol 
542 hexakisphosphate method. Phytic acid is presented as the \% of phytate per 100 grams of seeds.

543 Values are Mean \pm Stnd Dev $(n=4)$. Different letters indicate statistical differences at a $P<0.05$

544 (Duncan t-test).

545 Figure 3. Total Protein content of $\boldsymbol{C}$. quinoa seeds. Total protein content was determined by

546 using the Kjeldahl method in seeds of Regalona, Salcedo-INIA and Titicaca cultivars grown in

547 Chile, Peru or Spain. Values are Mean \pm Stnd Dev $(n=3)$. Different letters indicate statistical

548 differences at a $P<0.05$ (Duncan t-test).

549 Figure 4. Free amino acid composition of $C$. quinoa seeds from different cultivars and

550 locations. Amino acid contents of a pool of $10 \mathrm{~g}$ of $C$. quinoa seeds were determined by using

551 LC/MS. Seeds of different cultivars including Regalona, Salcedo-INIA and Titicaca were obtained

552 from different locations (Chile, Peru or Spain). Values are Mean $\pm \mathrm{SE}(\mathrm{n}=4)$. Different letters

553 indicate statistical differences at a $P<0.05$ (Tukey t-test).

554 Figure 5. Variation of antioxidant properties of $C$. quinoa seeds of different cultivars and

555 locations. Antioxidant properties were determined by using FRAP in seeds of Regalona, Salcedo-

556 INIA and Titicaca cultivars grown in Chile, Peru or Spain. Values are Mean \pm Stnd Dev $(n=3)$.

557 Different letters indicate statistical differences at a $P<0.05$ (Duncan t-test).

558 Figure 6. Saponin and fiber contents of $C$. quinoa seeds from three cultivars grown at three

559 different locations. (a) Saponin and (b) fiber contents were determined in Regalona, Salcedo-

560 INIA and Titicaca seeds obtained at three different locations (Chile, Peru or Spain). Values are

561 Mean \pm Stnd Dev ( $\mathrm{n}=3$ ). Different letters indicate statistical differences at a $P<0.05$ (Duncan

562 test). 
563 Table 1. Agronomical traits of three Chenopodium quinoa cultivars growing under different 564 agroecological conditions. Different letters indicate statistical differences at a $P<0.05$ (Duncan t565 test). Regalona and Titicaca varieties did not prosper on Peru.

566 Supplementary Table 1. Absolute values of mineral of three cultivars of $C$. quinoa seeds growing 567 at three different locations. Values are Mean \pm Stnd Dev $(n=4)$.

568 Supplementary Table 2. Amino acid content of three Chenopodium quinoa cultivars growing under 569 different agroecological conditions. Different letters indicate statistical differences at a $P<0.05$ (Duncan 570 t-test). Values represent Mean $\pm \mathrm{SE}$. 


\section{Table $\mathbf{1}$ (on next page)}

Agronomical traits of three Chenopodium quinoa cultivars growing under different agroecological conditions

Different letters indicate statistical differences at a $P<0.05$ (Duncan t-test. 
Table 1. Agronomical traits of three Chenopodium quinoa cultivars growing under different agroecological conditions. Different letters indicate statistical differences at a $P<0.05$ (Duncan t-test).

\begin{tabular}{|c|c|c|c|c|c|c|c|c|c|c|c|}
\hline Variety & Location & Yield kg/ha & $\begin{array}{l}\text { Seed weight } \\
\text { per plant (g) }\end{array}$ & $\begin{array}{c}\text { Harvest } \\
\text { index }\end{array}$ & $\begin{array}{c}\text { Plant height } \\
\text { (m) }\end{array}$ & $\begin{array}{l}\text { Stem diameter } \\
\text { (cm) }\end{array}$ & $\begin{array}{c}\text { Panicle } \\
\text { length }(\mathrm{cm})\end{array}$ & $\begin{array}{c}\text { Panicle } \\
\text { diameter } \\
\text { (cm) }\end{array}$ & $\begin{array}{c}\text { Plant weight } \\
\text { (g) }\end{array}$ & $\begin{array}{c}\text { Days to } \\
\text { flowering }\end{array}$ & $\begin{array}{c}\text { Days to } \\
\text { maturity }\end{array}$ \\
\hline Regalona & Chile & 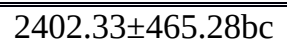 & 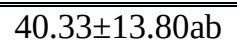 & $0.42 \pm 0.22 \mathrm{a}$ & $1.30 \pm 0.06 \mathrm{ab}$ & 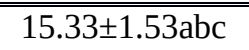 & $17.00 \pm 1.00 \mathrm{~d}$ & $11.00 \pm 1.00 \mathrm{~b}$ & $103.00 \pm 18.08 \mathrm{ab}$ & 70 & 165 \\
\hline Salcedo & Chile & $2743.33 \pm 80.13 b$ & $36.67 \pm 7.02 b c$ & $0.47 \pm 0.09 a$ & $0.84 \pm 0.09 \mathrm{e}$ & $11.33 \pm 1.53 \mathrm{e}$ & $31.66 \pm 3.51 b$ & $7.00 \pm 0.00 \mathrm{~d}$ & $78.00 \pm 2.65 \mathrm{~cd}$ & 100 & 180 \\
\hline Titicaca & Chile & $4300.33 \pm 1841.58 a$ & $42.67 \pm 9.71 \mathrm{ab}$ & $0.50 \pm 0.00 \mathrm{a}$ & $1.04 \pm 0.09 \mathrm{~d}$ & $12.00 \pm 1.00 \mathrm{de}$ & $22.33 \pm 2.08 c$ & $7.00 \pm 0.00 \mathrm{~d}$ & $86.00 \pm 19.31 b c$ & 50 & 105 \\
\hline Salcedo & Peru & $5170.00 \pm 142.82 a$ & $26.40 \pm 1.14 \mathrm{c}$ & $0.40 \pm 0.00 \mathrm{a}$ & $1.36 \pm 0.01 \mathrm{a}$ & $18.25 \pm 0.50 \mathrm{a}$ & $35.50 \pm 1.29 a$ & $15.60 \pm 0.71 \mathrm{a}$ & $66.00 \pm 2.58 d$ & 65 & 145 \\
\hline Regalona & Spain & $2606.00 \pm 0.00 \mathrm{bc}$ & $50.60 \pm 9.58 a$ & $0.47 \pm 0.04 a$ & $1.25 \pm 0.05 b c$ & $14.80 \pm 2.28 \mathrm{bcd}$ & $20.00 \pm 2.55 \mathrm{~cd}$ & $12.00 \pm 1.58 \mathrm{~b}$ & $107.80 \pm 15.06 \mathrm{a}$ & 63 & 138 \\
\hline Salcedo & Spain & * & $*$ & $*$ & $1.36 \pm 0.06 a$ & $16.80 \pm 2.77 \mathrm{ab}$ & $36.00 \pm 2.55 a$ & $9.00 \pm 1.00 \mathrm{c}$ & $*$ & 92 & 187 \\
\hline Titicaca & Spain & $1526.00 \pm 0.00 \mathrm{c}$ & $37.20 \pm 4.66 \mathrm{abc}$ & $0.42 \pm 0.03 a$ & $1.15 \pm 0.03 \mathrm{c}$ & $12.20 \pm 1.30$ cde & $28.00 \pm 2.35 b$ & $7.00 \pm 1.00 \mathrm{~d}$ & $89.60 \pm 7.67 a b c$ & 51 & 119 \\
\hline
\end{tabular}

(*) Seed losses were detected due to defects related to the timing of maturity, the uniformity of maturity and the drydown of plant at seed maturity

Titicaca and Regalona were unable to grow in Peru at the time the experiment was performed. 


\section{Figure 1 (on next page)}

Mineral composition of three cultivars of $C$. quinoa seeds growing at three different locations

Quantitative multi-elemental analysis was performed using inductively coupled plasma (ICP) spectrometry and the total content of $\mathrm{P}, \mathrm{K}, \mathrm{Ca}, \mathrm{Mg}, \mathrm{Fe}, \mathrm{Na}$ and $\mathrm{Zn}$ were determined. Three cultivars (Regalona, Salcedo-INIA and Titicaca) grown at three different locations (Peru, Chile and Spain) were used to evaluate changes in the mineral composition associated with different agroecological conditions. (A-C) Mineral composition of one variety comparing among countries (Red: Chile; Black: Peru; Blue: Spain) (A) Regalona, (B) Salcedo-INIA and (C) Titicaca. (D-E) Mineral composition of seeds from Spain or Chile comparing among varieties (Red: Regalona; Black: Salcedo-INIA; Blue: Titicaca), (D) Chile and (E) Spain. Values are presented as the Mean relative to the maximum and minimum values for each element $(n=4)$. Asterisks indicate statistical differences at a $P<0.05$ (Tukey t-test or Student t-Test when comparing pairs). When more than 2 samples are compared, colored asterisks indicate the sample that is statistically significant. 


\section{A. Regalona PeerJ B. Salcedo Manuscript to be reved Titicaca}
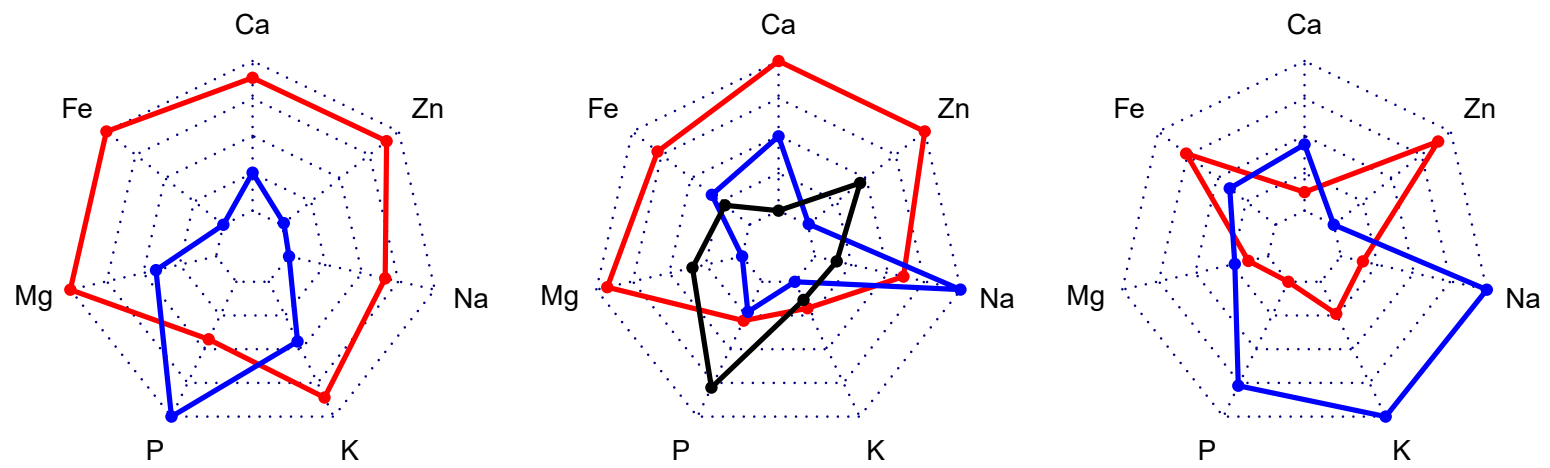

D.

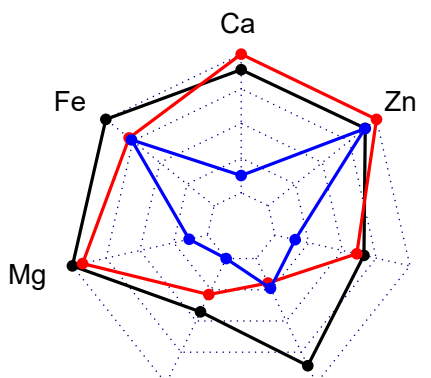

$\mathrm{P}_{\text {Peer reviewing PDF } 1 \text { (2018:012:23 }} \mathrm{K}$
E. Spain

Ca

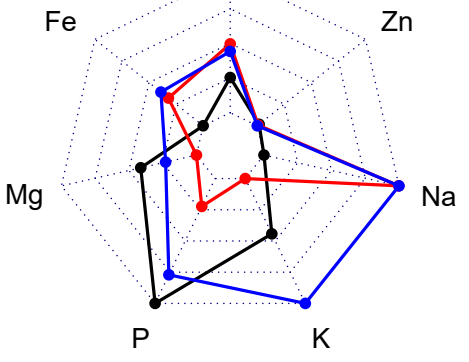


Figure 2 (on next page)

Phytic acid content among three varieties of $C$. quinoa seeds growing at different locations.

Phytic acid content of quinoa seeds was determined using the myo-inositol hexakisphosphate method. Phytic acid is presented as the $\%$ of phytate per 100 grams of seeds. Values are Mean \pm Stnd Dev $(n=4)$. Different letters indicate statistical differences at a $P<0.05$ (Duncan t-test). 


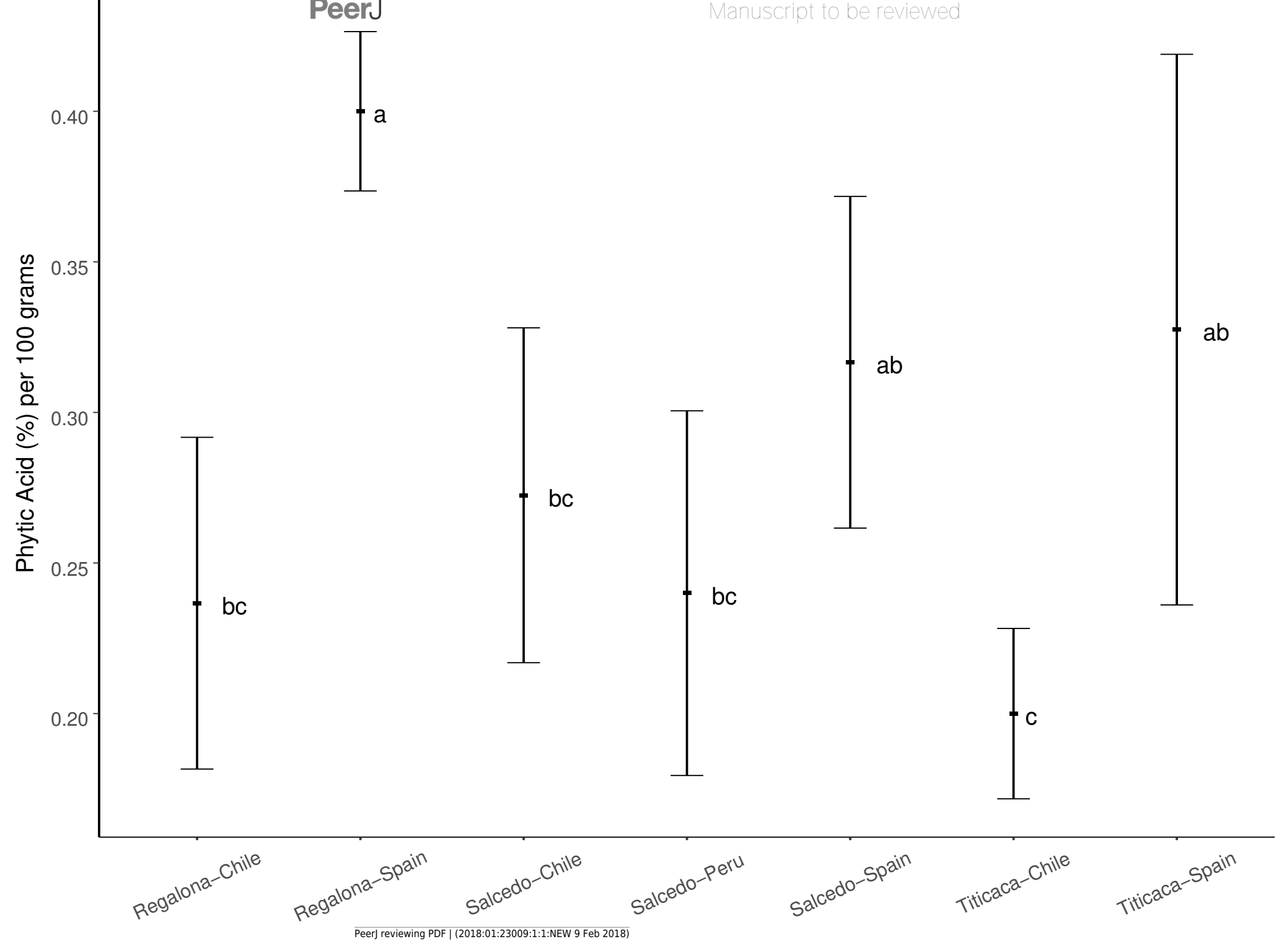


Figure 3 (on next page)

Total Protein content of $C$. quinoa seeds

Total protein content was determined by using the Kjeldahl method in seeds of Regalona, Salcedo-INIA and Titicaca cultivars grown in Chile, Peru or Spain. Values are Mean \pm Stnd Dev $(n=3)$. Different letters indicate statistical differences at a $P<0.05$ (Duncan t-test). 


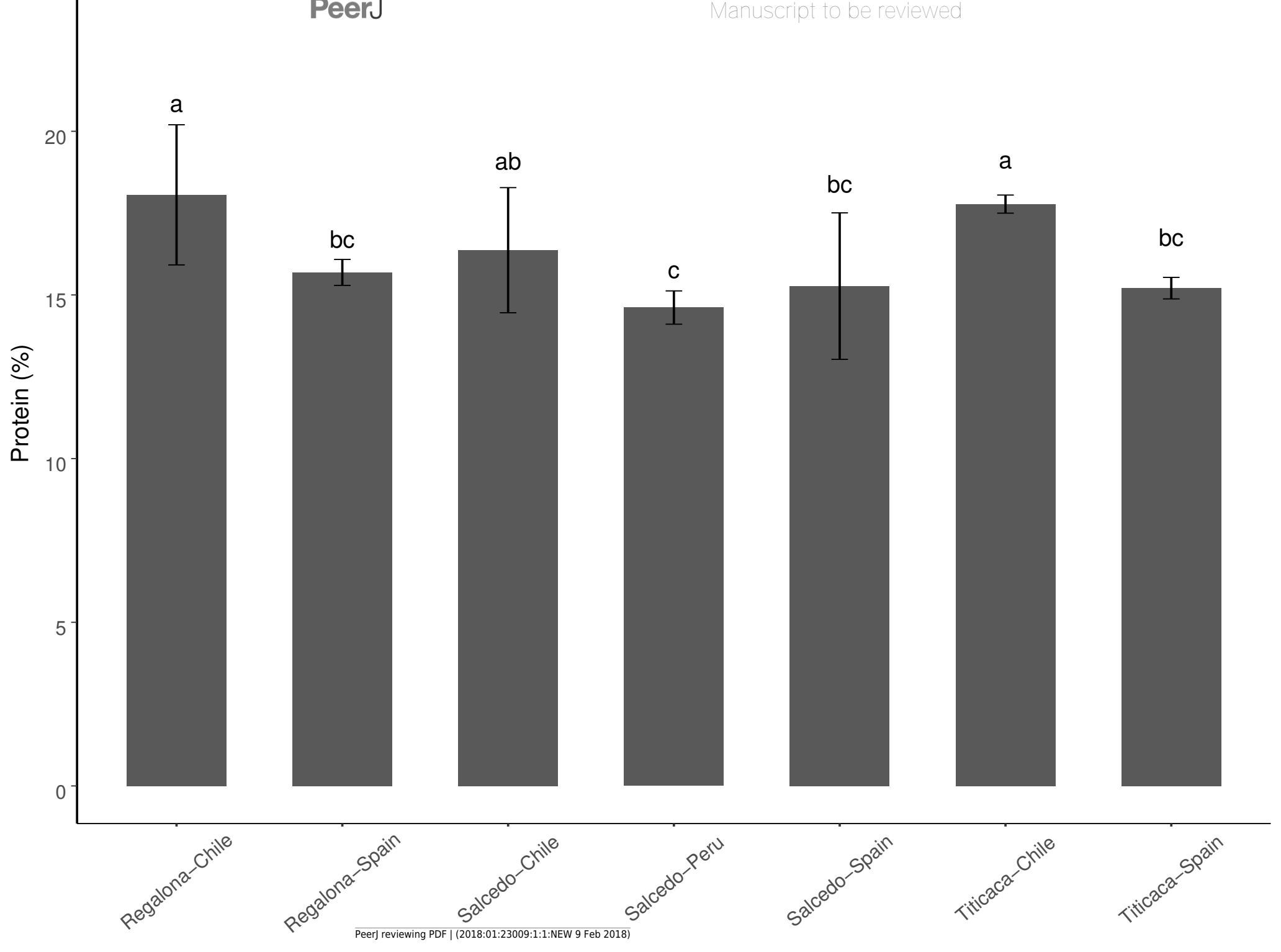


Figure 4 (on next page)

Free amino acid composition of $C$. quinoa seeds from different cultivars and locations.

Amino acid contents of a pool of $10 \mathrm{~g}$ of $C$. quinoa seeds were determined by using LC/MS.

Seeds of different cultivars including Regalona, Salcedo-INIA and Titicaca were obtained from different locations (Chile, Peru or Spain). Values are Mean $\pm S E(n=4)$. Different letters indicate statistical differences at a $P<0.05$ (Tukey t-test). 


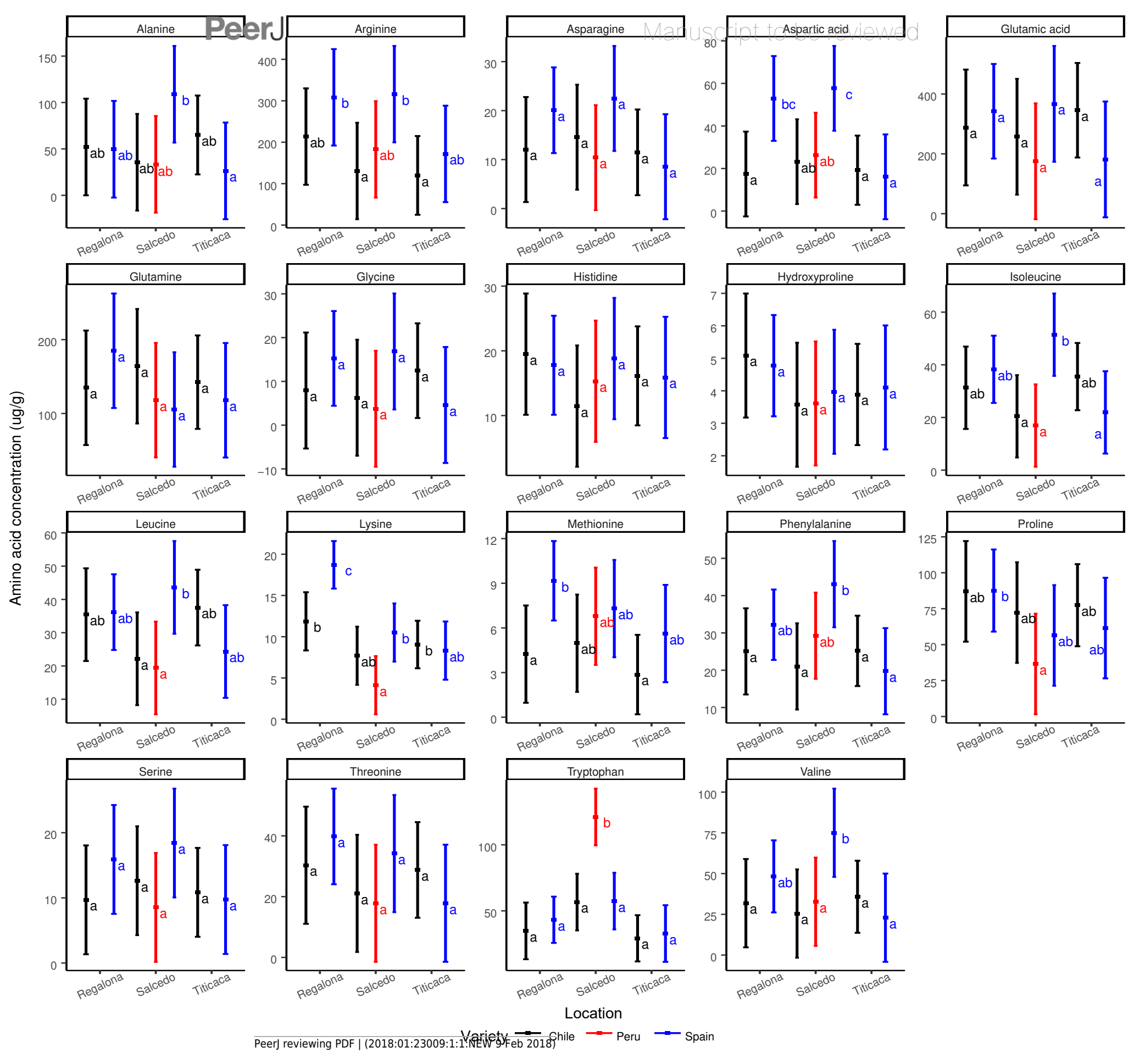


Figure $\mathbf{5}$ (on next page)

Variation of antioxidant properties of $C$. quinoa seeds of different cultivars and locations

Antioxidant properties were determined by using FRAP in seeds of Regalona, Salcedo-INIA and Titicaca cultivars grown in Chile, Peru or Spain. Values are Mean \pm Stnd Dev $(n=3)$. Different letters indicate statistical differences at a $P<0.05$ (Duncan t-test). 


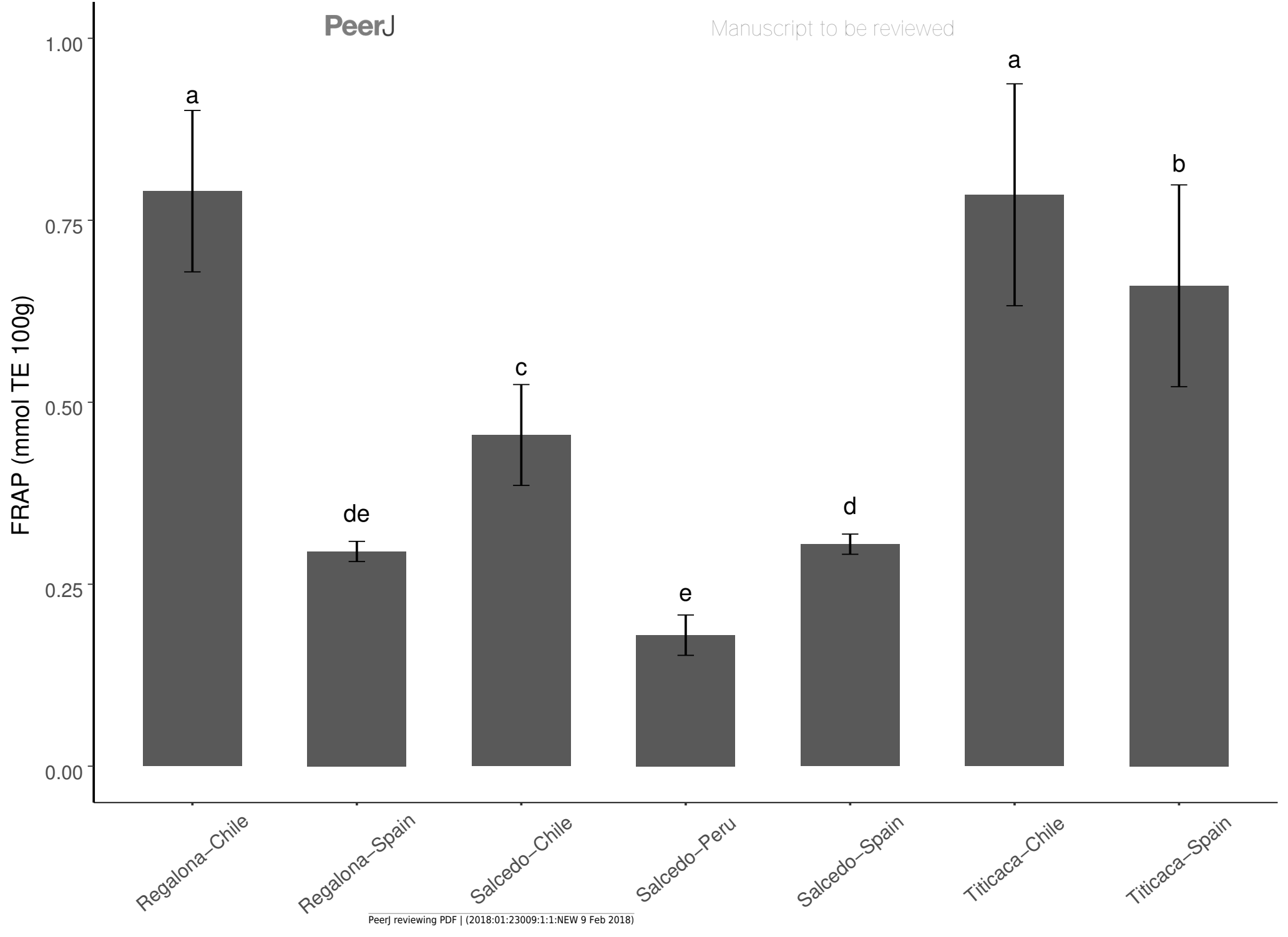


Figure $\mathbf{6}$ (on next page)

Saponin and fiber contents of $C$. quinoa seeds from three cultivars grown at three different locations.

(a) Saponin and (b) fiber contents were determined in Regalona, Salcedo-INIA and Titicaca seeds obtained at three different locations (Chile, Peru or Spain). Values are Mean \pm Stnd $\operatorname{Dev}(n=3)$. Different letters indicate statistical differences at a $P<0.05$ (Duncan test). 
